CORRECTION

\title{
Correction to: Ice nucleation in a Gram-positive bacterium isolated from precipitation depends on a polyketide synthase and non-ribosomal peptide synthetase
}

Kevin C. Failor, Haijie Liu, Marco E. Mechan Llontop, Sophie LeBlanc, Noam Eckshtain-Levi, Parul Sharma, Austin Reed, Shu Yang (D, Long Tian, Christopher T. Lefevre (iD), Nicolas Menguy, Liangcheng Du (D), Caroline L. Monteil (iD) and Boris A. Vinatzer (i)

(c) The Author(s) 2021

The ISME Journal (2022) 16:901; https://doi.org/10.1038/s41396-021-01174-8

Correction to: The ISME Journal https://doi.org/10.1038/s41396021-01140-4, published online 23 October 2021

The middle initial was missing from the author Lefevre.

It should be Christopher T. Lefevre

The original article has been corrected.

\begin{abstract}
(i) Open Access This article is licensed under a Creative Commons Attribution 4.0 International License, which permits use, sharing, adaptation, distribution and reproduction in any medium or format, as long as you give appropriate credit to the original author(s) and the source, provide a link to the Creative Commons license, and indicate if changes were made. The images or other third party material in this article are included in the article's Creative Commons license, unless indicated otherwise in a credit line to the material. If material is not included in the article's Creative Commons license and your intended use is not permitted by statutory regulation or exceeds the permitted use, you will need to obtain permission directly from the copyright holder. To view a copy of this license, visit http://creativecommons. org/licenses/by/4.0/.
\end{abstract}

(c) The Author(s) 2021 